\title{
Testing Travel Intention Model: An Empirical Study of Borobudur Temple
}

\author{
Elvin Alvandi, Dellazenda and Sabrina O. Sihombing \\ Faculty of Economics and Business, Universitas Pelita Harapan, Tangerang \\ Email: sabrina.sihombing@uph.edu
}

\begin{abstract}
This research aims to test the travel intention model that includes several main variables in predicting travel intention. Specifically, Borobudur temple was used to test the model because the temple was one of world heritage. Respondents were chosen by judgemental sampling and the sample size was 240. This research applied structural equation modelling to test research hypotheses. All research hypotheses were supported by data. This manuscript provide the literature review along with the development of hypotheses, research method, results and discussion, and research limitations and conclusion.
\end{abstract}

Keywords: travel intention, traditional WOM, commercial e-WOM, attitude, heritage image.

\begin{abstract}
Abstrak: Penelitian ini bertujuan untuk menguji model niat perjalanan yang mencakup beberapa variabel utama dalam memprediksi niat perjalanan. Secara khusus, candi Borobudur digunakan untuk menguji model karena candi adalah salah satu warisan dunia. Responden dipilih dengan judgemental sampling dan ukuran sampel adalah 240. Penilitian ini menggunakan modelpersamaan struktural untuk menguji hipotesis penelitian. Semua hipotesis penelitian didukung oleh data. Naskah ini menyampaikan tinjauan literatur bersama dengan pengembangan hipotesis, metode penelitian, hasil dan diskusi, dan keterbatasan penelitian dan kesimpulan.
\end{abstract}

Kata kunci: niat perjalanan, WOM tradisional, e-WOM komersial, sikap, citra warisan.

\section{INTRODUCTION}

Along with the times, Indonesia has had cultural heritage sites and has diverse tourism destinations. One of Indonesia's cultural heritage sites protected by UNESCO is the Borobudur temple. According to UNESCO, Borobudur temple is one of the famous world heritage and entered the world heritage list with the number C592 in 1991. Therefore, BUMN manages Borobudur temple to attract local and foreign tourists through a limited liability company, PT. Borobudur, Prambanan and Ratu Boko Temple Parks. In the management and utilization of Borobudur temple as a tourist attraction it turned out to have an impact on the cultural heritage's important values as well as the social, economic, cultural, and tourism impacts of Borobudur temple to the surrounding communities. Viewed from a tourism perspective, Borobudur temple is a cultural asset that has a high historical value. As a historical object, studies of these artefacts are still being carried out. In 2017 
based on the Central Bureau of Statistics of Magelang Regency, Borobudur temple has been visited by tourists of 3,556,642 domestic and foreign tourists.

As one of world heritage, this research aims to assess the impact antecedent variables of travel intention to Borobudur temple. This research replicated the travel intention model developed by (Mehmood et al., 2018). The important of the model to be replicated because there is not many literature that integrates antecedent variables in predicting travel intention to heritage sites (Mehmood et al., 2018). Moreover, not many studies include technologyrelated variables such as user-generated content (hereafter UGC) and commercial word-ofmouth in predicting travel intention. In fact, electronic transmission (e.g., commercial and UGC) has a significant role in the e-commerce era, especially in the re-creation and acquisition of tourists (Jalilvand et al., 2011). Therefore, this research aims to test travel intention model by using Borobudur temple as a research object.

\section{THEORETICAL REVIEW}

Travel Intention. Travel intentions are one's desire to travel or a commitment to travel that is likely to travel to a destination (Ahn et al., 2013). Tourism behavior is influenced by rational and affective conditions (Wu, 2015). Travel intentions are defined as the desire to visit a place. The decision to visit a place refers to calculation between the costs and benefits obtained from several alternative place choices available, which choices are obtained from external information including commercial electronic treads or blogs (Chen et al., 2014).

The travel intention to heritage site can be influenced by many factors. Specifically, according to a model developed by (Mehmood et al., 2018), travel intention is predicted by several main variables as follows: traditional word-of-mouth, commercial WOM, UGC, heritage image, and attitudes towards heritage site (Figure 1).

Figure 1. The Travel Intention Model

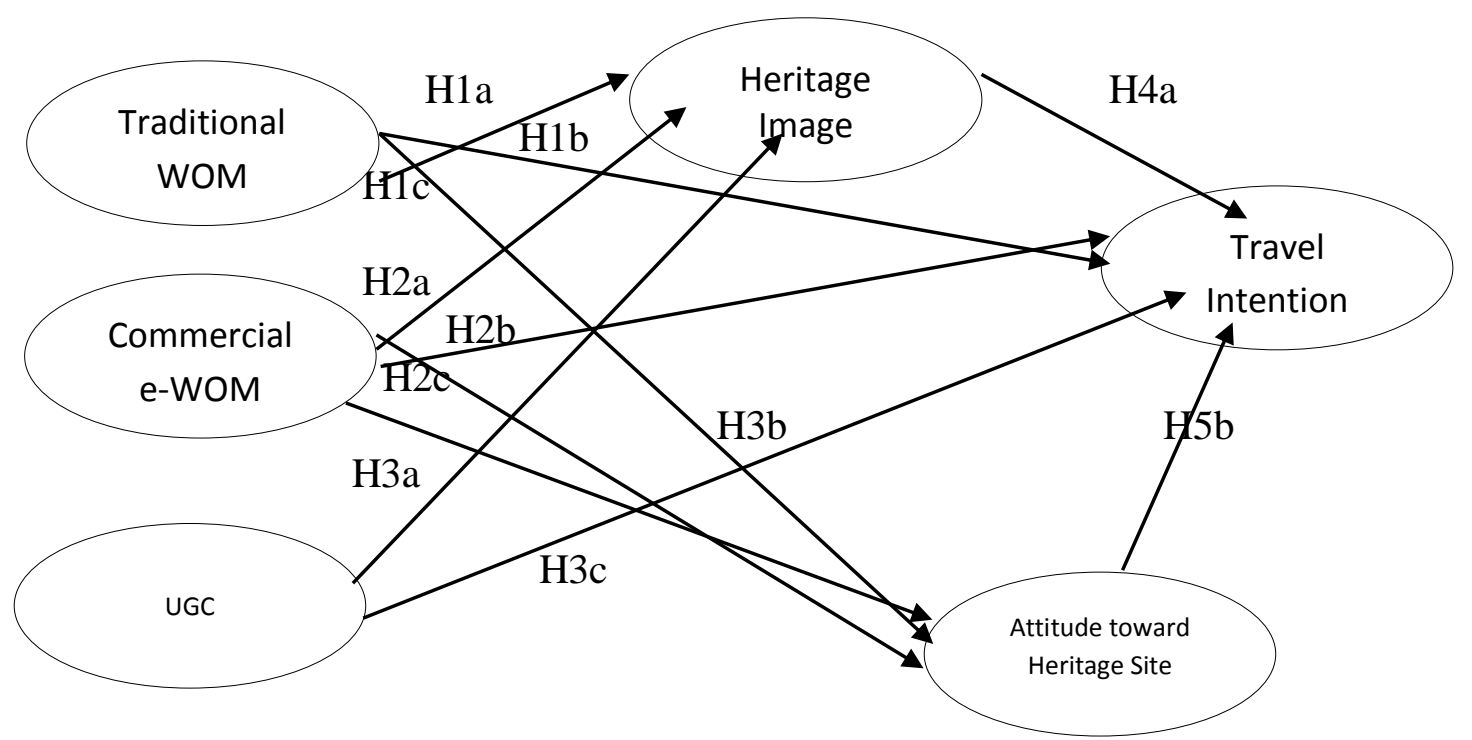

Source: (Mehmood et al., 2018) 


\section{The Relationship between Variables}

The relationship between Traditional WOM and Heritage Image. WOM is the act of people giving information to other consumers from someone to other people (interpersonal) non-commercial both brands, products and services. Every day people talk to others, exchange ideas, exchange information, comment on each other and other communication processes. Recent studies have shown that traditional word-of-mouth, among other sources of information, has a positive and significant influence on cultural image (Mahpour et al., 2018). A good image of a tourist destination contributes positively to the development and progress of the tourism object in question. Based on this, it is important for all parties involved in the tourism industry to do various things to improve the image of a tourist destination. Many ways can be done to improve the image of tourist destinations. According to (Isa and Ramli, 2014) specifically found that traditional word-of-mouth was able to mediate the effect of motivation on travel intentions. Previous studies also emphasized important elements that have a significant impact on increasing travel intentions (Abubakar and Ilkan et al., 2017). According to (Mehmood et al., 2016), tourists use strong bonds based on traditional information on word-of-mouth for decision making and cultural image formation. The positive influence of attitude towards heritage sites has been shown by previous studies (Mahpour et al., 2018; Tan, 2017; Whang et al., 2016). Therefore, it can be stated that heritage image, attitudes towards cultural heritage and travel intentions can be influenced by traditional WOM. The hypotheses can be stated as follows:

H1a: The better the traditional WOM, the higher the heritage image.

H1b: There better the traditional WOM, the higher travel intention.

H1c: The better the traditional WOM, the higher attitudes towards heritage site.

The relationship between Commercial e-WOM and Heritage Image. Commercial is describing a product or service that can be purchased by the public. Meanwhile, electronic transmission is an informal information dissemination activity through word of mouth through the internet or online websites (Lamba and Agarwal, 2014). Both of these definitions can be concluded that commercial electronic represents a service that can be purchased by the public through informal information dissemination activities through word of mouth through the internet media or online websites. Recent studies have shown that commercial electronic, among other sources of information, has significant influence on heritage image and travel intention (Tan, 2017; Abubakar and Ilkan, 2016). The commercial electronic market also plays an important role in creating the heritage image created by tourists after their holidays.

According to (Ladhari and Michaud, 2015), a study shows that an easy way for tourists looking for information about travel destinations is the commercial use of electronic word-of-mouth. Still in Ladhari and Michaud, the intention of the trip to visit the hotel was also positively influenced by the information originating from commercial electronic treads. Then, commercial electronic pick-up is positively influential in helping tourists to find information about determining the intention of travel to certain places (Abubakar and Ilkan, 2016). (Di Pietro et al., 2012) found that commercial electronic communication had a significant positive effect on attitudes toward objects. Thus, heritage image, travel intentions 
and attitudes towards heritage site can be influenced by the electronic word-of-mouth. Thus, the research hypotheses can be stated as follows:

H2a: The better the commercial e-WOM, the higher heritage image.

H2b: The better the commercial e-WOM, the higher travel intentions.

H2c: The better the commercial e-WOM, the higher attitude toward heritage site.

The Relationship between UGC and Image, Attitude, and Intention. UGC is various types of content that are publicly available and produced by end users (Andeas, 2010). (Vermeulen and Seegers, 2009) stated that the intention of a traveler shows an increasing tendency when they review the comments and opinions of other consumers who already have experience of these attractions. Previous studies show that destination's image has a positive and significant effect on tourist destinations in determining their travel intention (Ishida et al., 2016; Nassar et al., 2015; Jalilvand et al., 2013).

Online information provided by other users is considered more important and reliable and trustworthy than information provided by marketers. It can be stated that the information generated by consumers is important because consumers of products and services, especially those related to tourism and hospitality, are generally relying on the opinions and advice provided by other users who have experienced the service. Previous research also emphasized important elements that had a significant impact on attitudes towards heritage sites (Mahpour et al., 2018; Tan, 2017; Whang et al., 2016). Thus, heritage image, travel intentions, and attitudes towards heritage site can be influenced by user-generated content. Thus, hypotheses are developed as follows:

H3a: The greater user-generated content, the higher heritage image.

H3b: The greater user-generated content, the higher travel intention.

H3c: The greater user-generated content, the higherattitude toward heritage site.

The Relationship between Heritage Image and Travel Intention. Image is a set of beliefs, ideas, and a person's impression of a certain object (Ruslan, 2014). While culture is recognised as complex that includes knowledge, beliefs, art, morals, customs and abilities and other habits possessed by humans as part of society (Hawkins and Mothersbaugh, 2010). Previou studies shows that decisions regarding travel intentions have significantly influenced by the image of the destinations held by certain tourist attractions (Tan, 2017; Whang et al., 2016; Jalilvand et al., 2012). Thus, it can be stated that:

H4a: The greater the heritage image, the higher travel intentions.

Heritage Image as a Mediating Variable. In a travel intention model developed by (Mehmood et al., 2018), heritage image is as variable that mediates between the commercial e-WOM with travel intentions. Furthermore, this model also shows that heritage image is as variable that mediate between UGC and travel intentions. Thus, it can be stated that

H4b: The heritage image mediates the relationship between traditional WOM and travel intention. 
H4c: The heritage image mediates the relationship between commercial e-WOM and travel intention.

H4d: The heritage image mediates the relationship between UGC and travel intention.

The Relationship between Attitude towards Heritage Site and Travel Intention. Attitudes towards heritage site are considered as attitudes towards objects. Research shows that attitude is a significant variable in predicting behavior. In the context of tourism, tourist attitude refers to the evaluation of the tourism object. Therefore, it can be stated that:

H5a: The greater the attitudes towards heritage site, the higher travel intention.

Attitude toward Heritage Site as Mediating Variable. (Mehmood et al., 2018) developed in their model that attitude towards heritage site mediates between the relationship of usergenerated content and travel intention. Thus, the research hypothesis can be stated as follows:

H5b: The heritage site mediates the positive relationship between traditional WOM and travel intention.

H5c: The heritage site mediates the positive relationship between commercial e-WOM and travel intention.

H5d: The attitude towards the heritage site mediates the positive relationship of UGC and travel intention.

\section{METHODOLOGY}

This research applied a quantitative paradigm. Specifically, this research is descriptive or also known as predictive research aimed at testing hypotheses. All research indicators are based on previous studies (Mehmood et al., 2018; Pratiwi, 2017). The interval scale is applied in a questionnaire where the Likert scale is integrated. Data is collected through a privately managed questionnaire and an electronic questionnaire. Specifically, sampling is applied with one main criterion that respondents have visited Borobudur Temple for at least the last two years. The sample size involved 240 respondents. There are two justifications for sample size. First, according to (Kock and Hadaya, 2018), the number of samples between 5 to 10 times is greater than the number of indicator variables. In this study there are 24 indicators, this figure is the minimum number in distributing questionnaires so that the number of samples used for this study is 50 samples. Second, the sample size for SEM analysis ranges from 100 to 200 samples (Wolf et al., 2013). In other words, the use of samples of 100 and above in accordance with the rule of thumb.

The tests of reliability and validity were performed before data was processed for hypothesis testing. All data are then analysed using structural equation modelling (SEM). SEM can be used to analyse research models that have several independent (exogenous) and dependent (endogenous) variables as well as moderating or intervening variables. More specifically SEM provides several benefits and advantages for researchers, such as confirm the theory according to the research data, and able to explain the complex interrelationships of variables and the direct or indirect effects of one or several variables on other variables. 


\section{THE RESULTS OF STATISTICAL TESTS}

The questionnaire were distributed to 240 respondents. Two hundred and twenty three questionnaires were returned by respondents. After checking all questionnaires, 194 questionnaires can be further proceed giving $86.9 \%$ usable response rates.

From 194 respondents' data processing, the results show that the majority of respondents were aged 21-25 years old, as many as 117 respondents or $60.6 \%$ of the total age of the respondents. Furthermore, in the most recent education respondents who were owned by researchers were mostly Senior High Schools with 128 respondents or $66.3 \%$. The reason for going to Borobudur temple was answered as for vacation with 146 respondents or $75.6 \%$. Thus, it can be concluded that the majority of respondents are aged between 21-25 years, have completed senior high school education, and their destination to the Borobudur temple is vacation.

Table 1 shows the result of reliability tests. All Cronbach alpha coefficient were above 0.70 . In other words, all variables indicators were reliable. Then, Table 2 shows convergent and discriminant validity tests which shows that convergent and validity criterion were achieved.

Table 1. Reliability Tests

\begin{tabular}{c|c|c|c|}
\hline Variable & Indicators & $\begin{array}{c}\text { Cronbach's Alpha } \\
\text { coefficient }\end{array}$ & $\begin{array}{c}\text { Corrected Item- } \\
\text { Total Correlation }\end{array}$ \\
\hline Traditional WOM & TW1 & .967 & .945 \\
& TW2 & .895 \\
TW3 & & .919 \\
TW4 & .974 & .907 \\
\hline Commercial & CW1 & & .941 \\
WOM & CW2 & & .928 \\
User Generated & CW3 & .941 \\
Content & UGC1 & .970 & .931 \\
\hline UGC 2 & & .941 \\
& UGC 3 & .908 \\
& UGC 4 & .945 \\
& HI1 & .905 \\
\hline Attitude toward & HI2 & & .932 \\
Heritage Site & HI3 & & .910 \\
& ATHS1 & & .920 \\
& ATHS2 & .966 & .913 \\
\hline Travel Intention & ATHS3 & & .890 \\
& ATHS4 & & .915 \\
& TI1 & & .933 \\
& TI2 & & .920 \\
\hline
\end{tabular}


Table 2. Convergent and Discriminant Validity Results

\begin{tabular}{|l|c|c|c|}
\hline \multicolumn{1}{|c|}{ Variable } & CR & AVE & $\begin{array}{c}\text { Diskriminant } \\
\text { Fornell- } \\
\text { Larcker }\end{array}$ \\
\hline Traditional WOM & 0.967 & 0.880 & 0.938 \\
Commercial WOM & 0.974 & 0.905 & 0.951 \\
User Generated Content & 0.970 & 0.892 & 0.944 \\
Heritage Image & 0.968 & 0.882 & 0.939 \\
Attitude Toward the Heritage & 0.966 & 0.876 & 0.936 \\
Site & 0.971 & 0.894 & 0.946 \\
Travel Intention & \multicolumn{3}{|l}{} \\
\hline
\end{tabular}

Data analyzed using structural equation modeling shows the results that all hypotheses are supported (Table 3). Table 4 shows the goodness of fit (GOF) of several indexes representing the model were fit with the data.

Table 3. Hypotheses Testing Results

\begin{tabular}{c|l|c|c|c|c}
\hline $\begin{array}{c}\text { Hypho- } \\
\text { teses }\end{array}$ & \multicolumn{1}{|c|}{ Path } & Estimate & $\begin{array}{c}\text { Critical } \\
\text { Ratio }\end{array}$ & P-value & Conclusion \\
\hline $\mathrm{H}_{1 \mathrm{a}}$ & $\begin{array}{l}\text { Traditional WOM -> } \\
\text { Heritage Image }\end{array}$ & 0,240 & 2,983 & 0,003 & Supported \\
\hline $\mathrm{H}_{1 \mathrm{~b}}$ & $\begin{array}{l}\text { Traditional WOM -> } \\
\text { Travel Intention }\end{array}$ & 0,197 & 2,638 & 0,008 & Supported \\
\hline $\mathrm{H}_{1 \mathrm{c}}$ & $\begin{array}{l}\text { Traditional WOM -> } \\
\text { Attitude toward Heritage } \\
\text { Image }\end{array}$ & 0,224 & 3,521 & 0,000 & Supported \\
\hline $\mathrm{H}_{2 \mathrm{a}}$ & $\begin{array}{l}\text { Commercial WOM -> } \\
\text { Heritage Image }\end{array}$ & 0,183 & 2,671 & 0,008 & Supported \\
\hline $\mathrm{H}_{2 \mathrm{~b}}$ & $\begin{array}{l}\text { Commercial WOM -> } \\
\text { Travel Intention }\end{array}$ & 0,166 & 2,660 & 0,008 & Supported \\
\hline $\mathrm{H}_{2 \mathrm{c}}$ & $\begin{array}{l}\text { Commercial WOM -> } \\
\text { Attitude toward Heritage } \\
\text { Image }\end{array}$ & 0,148 & 2,746 & 0,006 & Supported \\
\hline $\mathrm{H}_{3 \mathrm{a}}$ & $\begin{array}{l}\text { User Generated Content - } \\
>\text { Heritage Image }\end{array}$ & 0,405 & 5,252 & 0,000 & Supported \\
\hline $\mathrm{H}_{3 \mathrm{~b}}$ & $\begin{array}{l}\text { User Generated Content - } \\
>\text { Travel Intention }\end{array}$ & 0,210 & 2,739 & 0,006 & Supported \\
\hline $\mathrm{H}_{3 \mathrm{c}}$ & $\begin{array}{l}\text { User Generated Content - } \\
\text { Attitude toward } \\
\text { Heritage Image }\end{array}$ & 0,285 & 4,667 & 0,000 & Supported \\
\hline $\mathrm{H}_{4 \mathrm{a}}$ & $\begin{array}{l}\text { Heritage Image -> Travel } \\
\text { Intention }\end{array}$ & 0,170 & 2,505 & 0,012 & Supported \\
\hline
\end{tabular}

Source: (Data analysis, 2019) 
Table 4. Goodness of Fit

\begin{tabular}{l|c|c|c}
\hline \multirow{2}{*}{ Goodnes of Fit Indicators } & \multicolumn{2}{|c|}{ Fit Indices } & \multirow{2}{*}{ Results } \\
\cline { 2 - 3 } & Good Fit & Marginal Fit & \\
\hline GFI & $\geq 0,90$ & $0,80-<0,90$ & 0,883 \\
RMSEA & $\leq 0,08$ & - & 0,043 \\
$\chi^{2} /$ df & $<2,0$ & - & 1,361 \\
CFI & $\geq 0,90$ & $0,80-<0,90$ & 0,987 \\
IFI & $\geq 0,90$ & $0,80-<0,90$ & 0,988 \\
NFI & $\geq 0,90$ & $0,80-<0,90$ & 0,955 \\
TLI & $\geq 0,90$ & $0,80-<0,90$ & 0,985 \\
RFI & $\geq 0,90$ & $0,80-<0,90$ & 0,947 \\
RMSR & $\leq 0,05$ & - & 0,032 \\
\hline
\end{tabular}

Source: (Data analysis, 2019)

Table 5 and 6 show the results of the mediation test. According to some researchers that partial mediation results from the effect of independent variables on the dependent variable decreasing and interactions are significant (Radzi et al., 2017). To test the effect of mediating variables between the effects of traditional WOM, commercial e-WOM, usergenerated content on travel intentions with attitude toward heritage site and heritage image as mediating variables are as follows:

Table 5. Direct Effect Results

\begin{tabular}{c|c|c|c}
\hline & $\begin{array}{c}\text { User Generated } \\
\text { Content }\end{array}$ & $\begin{array}{c}\text { Commercial } \\
\text { WOM }\end{array}$ & $\begin{array}{c}\text { Traditional } \\
\text { WOM }\end{array}$ \\
\hline $\begin{array}{c}\text { Attitude toward } \\
\text { Heritage Site }\end{array}$ & 0,285 & 0,148 & 0,224 \\
\hline Heritage Image & 0,405 & 0,183 & 0,240 \\
\hline Travel Intention & 0,210 & 0,166 & 0,197 \\
\hline
\end{tabular}

Source: (Data analysis, 2019)

Table 6. Indirect Effect Results

\begin{tabular}{c|c|c|c}
\hline & $\begin{array}{c}\text { User Generated } \\
\text { Content }\end{array}$ & $\begin{array}{c}\text { Commercial } \\
\text { WOM }\end{array}$ & $\begin{array}{c}\text { Traditional } \\
\text { WOM }\end{array}$ \\
\hline $\begin{array}{c}\text { Attitude toward } \\
\text { Heritage Site }\end{array}$ & 0,000 & 0,000 & 0,000 \\
\hline Heritage Image & 0,000 & 0,000 & 0,000 \\
\hline Travel Intention & 0,142 & 0,069 & 0,098 \\
\hline
\end{tabular}

Source: (Data analysis, 2019)

Tables 5 and 6 show whether the heritage image variable is a mediating variable between user-generated content and electronic commercial content on travel intentions by comparing the standardized values of direct effects and standardized indirect effects. In other words, if the standardized value of the direct effect is smaller than the standardized 
indirect effect, it can be stated that the mediating variable has an indirect effect on the relationship of the two variables (independent and dependent).

Table 7 shows the standardized total effect which is the sum of standardized direct effects and standardized indirect effects. The relationship between user-generated content and commercial e-WOM mediated heritage image on standardized travel intentions of direct effects with user-generated content variables (0.210) and commercial e-WOM (0.315). On standardized the indirect effect of user-generated content (0.142) and commercial e-WOM (0.069). Therefore, the standardized total effect of user-generated content variables $(0.352)$ and commercial e-WOM (0.235). Finally, Table 8 provides the conclusion of mediation effect.

Table 7. Total Effects

\begin{tabular}{l|c|c|c}
\hline & $\begin{array}{c}\text { User Generated } \\
\text { Content }\end{array}$ & $\begin{array}{c}\text { Commercial } \\
\text { WOM }\end{array}$ & $\begin{array}{c}\text { Traditional } \\
\text { WOM }\end{array}$ \\
\hline $\begin{array}{l}\text { Attitude toward } \\
\text { Heritage Site }\end{array}$ & 0,285 & 0,148 & 0,224 \\
\hline Heritage Image & 0,405 & 0,183 & 0,240 \\
\hline Travel Intention & 0,352 & 0,235 & 0,295 \\
\hline
\end{tabular}

Source: (Data analysis, 2019)

Table 8. Mediation Effects

\begin{tabular}{c|c|c|c|c|c|c|c|c}
\hline & IV & \multicolumn{2}{|c|}{ M } & DV & $\begin{array}{c}\text { Direct } \\
\text { Effect }\end{array}$ & $\begin{array}{c}\text { Indirect } \\
\text { Effect }\end{array}$ & $\begin{array}{c}\text { Total } \\
\text { Effects }\end{array}$ & Mediation \\
\hline $\begin{array}{c}\text { H4b and } \\
\text { H 5b }\end{array}$ & TW & HI & ATHS & TI & $0.197^{* *}$ & $0.098^{* *}$ & $0.295^{* * *}$ & Partial \\
\hline $\begin{array}{c}\text { H4c and } \\
\text { H5c }\end{array}$ & CW & HI & ATHS & TI & $0.166^{* *}$ & $0.069^{* *}$ & $0.235^{* * *}$ & Partial \\
\hline $\begin{array}{c}\text { H4d and } \\
\text { H5d }\end{array}$ & UGC & HI & ATHS & TI & $0.210^{* *}$ & $0.142^{* *}$ & $0.352^{* * *}$ & Partial \\
\hline
\end{tabular}

Source: (Data analysis, 2019)

\section{DISCUSSION}

From the hypothesis testing show all supported hypotheses. Hypothesis 1a states that the better the traditional WOM, the higher heritage image. Results show that the higher the traditional WOM to the Borobudur temple, the higher the heritage image as well. Furthermore, the better the physical environment of the Borobudur temple, the more comfortable the place. Visitors from the Borobudur temple can increasingly enjoy the views of the Borobodur temple. Results from data analysis also shows that average value of the indicators of the traditional WOM variable and the heritage image answering "agree", this indicates that the better the traditional WOM of this Borobudur temple, the higher the heritage image. This hypothesis is supported in accordance with previous studies where 
traditional WOM relates to heritage image namely (Jalilvand et al., 2013; Mahpour et al., 2018). Hypothesis $1 \mathrm{~b}$ shows that the greater the traditional WOM, then the higher intention to travel. These results indicate there is an influence between traditional WOM and travel intentions. Statistical data that shows that the majority of respondents answered indicators of the traditional WOM and travel intentions answered by "agreeing". Furthermore, the results of destrictive statistical testing for traditional WOM variables and respondents' travel intentions answered "agree". This hypothesis is supported as previous research by (Pratminingsih, 2014), (Isa and Ramli, 2014) and (Abubakar et al., 2017). Hypothesis 1c shows a positive relationship between traditional WOM and attitudes toward heritage site. This hypothesis is supported. Descriptive statistical shows that the indicators of traditional WOM and attitudes towards heritage site. From the results of these statistics indicate the average answer of the indicators of traditional WOM is "agree". From the results of these descriptive data it can be said that the traditional WOM determines their attitude towards the cultural heritage of the Borobudur temple.This hypothesis is supported in accordance with previous studies where traditional contagion is related to attitudes toward cultural heritage, namely (Mehmood et al., 2016), (Mahpour et al., 2018), (Tan, 2017), and (Whang et al., 2016).

Hypothesis 2a shows that the better the commercial e-WOM, the higher heritage image. Statistical data analysis shows that all indicators of commercial e-WOM and heritage image are answering "agree". This results supported as previous research by (Jalilvand and Samiei, 2012), (Setiawan et al., 2014), Tan, 2017), (Abubakar and Ilkan, 2016), (Jalilvand et al., 2012) and (Assaker et al., 2011). Hypothesis $2 \mathrm{~b}$ shows that the better the commercial e-WOM, the higher travel intentions. Tourists have the intention of traveling to the Borobudur temple according to the profile of respondents $61.1 \%$ of them came to the Borobudur temple in the last two years. Respondents have the intention of a great trip to the Borobudur temple which is influenced by the commercial e-WOM which is lively to discuss the Borobudur temple. The supported hypothesis can also be based from the majority of respondents answering "agreeing" from indicators of e-WOM commercial variables and travel intentions. This significant relationship between commercial e-WOM and travel intentions supported by previous research (e.g., Ladhari and Michaud, 2015; Abubakar and Ilkan, 2016; Abubakar et al., 2017; Jalilvand and Samiei, 2012). Hypothesis 2c shows that there better electronic e-WOM, the higher attitude toward heritage site. The reason can be seen from the descriptive statistical data, the average respondent answers "agree" to indicators of e-WOM commercial variables and attitudes towards cultural heritage. The result of this research similar with previous researchs (e.g., Zarrad and Debabi, 2015; Tussyadiah et al., 2018; Jalilvand and Samiei, 2012; Mahpour et al., 2018; Tan, 2017; Whang et al., 2016).

Hypothesis 3a states that the greater the user-generated content, the higher heritage image. The higher the content created by users owned by the Borobudur temple, the higher the heritage image as well. Results show that the average value of indicators of usergenerated content variables and cultural imagery answered "agree", this indicates that the better the user-generated content of the Borobudur temple, the better the image of the temple. This hypothesis is supported in accordance with previous studies in which usergenerated content is related to cultural imagery (e.g., O'Connor, 2010) which states that traditional WOM has a positive influence on heritage image. Hypothesis $3 \mathrm{~b}$ shows that the greater the user-generated content, the higher travel intention. These results indicate there 
is an influence between the content created by the user with the intention of the trip, if the content created by users at the Borobudur temple is good then tourists will intend more to visit the Borobudur temple. Statistical data that the majority of respondents answered indicators of user-generated content variables and travel intentions answered by "agreeing". The results of this research is similar with previous research by (Phau et al., 2010), (Abubakar et al., 2017), and (Nassar et al., 2015).

Hypothesis $3 \mathrm{c}$ shows that the greater user-generated content, the higher attitude toward heritage site. These results indicate there is an influence between user-generated content and attitude toward heritage site. Results show that all indicators of user-generated content variables and attitudes towards cultural heritage in response to "agree". The existence of a significant relationship between user-generated content and attitudes towards cultural heritage is supported in the same way as previous studies (e.g., Mahpour et al., 2018; Tan, 2017; Whang et al., 2016).

Results of hypothesis 4a shows the heritage image mediates the relationship between traditional WOM and travel intention. These results indicate there is an influence between heritage image and travel intention. It can be stated that the better the cultural image of the Borobudur temple, the greater the intention of tourists visiting the Borobudur temple. This result is similar with previous research (e.g., Ishida et al., 2016; Jalilvand et al., 2013; Abubakar et al., 2016; Mahpoor et al., 2018; Hidayat et al., 2017; Croy, 2014; Phau et al., 2010). Results also supported hypothesis $4 \mathrm{~b}$ that states that the heritage image mediates the positive relationship between traditional WOM and the intention to travel. Furthermore, results also shows that hypothesis $4 \mathrm{c}$ which states that the heritage image mediates the positive relationship between commercial electronic pick-up and travel intentions. Results show that hypothesis $4 \mathrm{~d}$ which states that the heritage image mediates the positive relationship between UGC and travel intention. The higher the content created by the user will produce a positive cultural image so that in the end will provide high travel intentions to the Borobudur temple.

Relating with hypotheses 4 (a,b,c, d), results show whether the heritage image variable becomes a mediating relationship between user-generated content and commercially eWOM with travel intention. This can be assessed by comparing the value of standardized direct effects and standardized indirect effects. This means that if the standardized value of the direct effect is smaller than the standardized indirect effect, it can be said that the mediating variable has an indirect effect in the relationship of the two variables (independent and dependent). User-generated content and commercial WOM to travel intentions seen from standardized direct effects of user-generated content, traditional WOM, commercial e-WOM with standardized indirect effect of user-generated content, and traditional WOM. Based on these data, it can be used to determine the relationship between user-generated content and commercial e-WOM mediated by heritage image against travel intentions, thus the indirect relationship between user-created content and electronic tread commercials mediated by cultural image mediated to travel intentions. Therefore, heritage image mediates in the influence of these relationships.

Hypothesis testing of $\mathrm{H} 5 \mathrm{a}$ shows there is a positive relationship between attitude toward heritage image and travel intention. Statistical data are indicators of attitudes towards heritage image and travel intention to answer "agree". This result was similar to previous research suah as (e.g., Tussyadiah et al., 2018; Mahpour et al., 2018; Tan, 2017; Whang et al., 2016; Abubakar and Ilkan, 2017; Abubakar and Ilkan, 2016). Hypothesis testing of H5b 
shows that there is a significant relationship between traditional WOM and travel intention is mediated by attitude toward heritage site. Results show that all indicators of traditional WOM, attitudes towards heritage site, and travel intentions in response to "agree". The existence of a positive relationship between traditional contagion and travel intentions mediated by attitudes toward cultural heritage is supported in the same way as previous research (e.g., Mahpour et al., 2018; Mahpour et al., 2018; Tan, 2017; Whang et al., 2016; Jalilvand et al., 2012; Abubakar and Ilkan, 2017; Abubakar and Ilkan, 2016; Jalilvand et al., 2013).

Results also supported thatH5c which shows a positive relationship between commercial e-WOM and heritage image is mediated by attitude toward heritage site. Statistical analysis shows that all indicators of commercial e-WOM, heritage image, and attitudes towards cultural heritage in response to "agree". This results is similar with previous research (e.g., Zarrad and Debabi, 2015; Jalivand et al., 2012; Abubakar and Ilkan, 2016; Whang et al., 2016; Reza et al., 2012; Abubakar and Ilkan, 2017; Mahpour et al., 2018; Tan, 2017; Whang et al., 2016). The result of hypothesis testing for H5d shows a positive relationship between UGC and travel intentions mediated by attitudes toward cultural heritage. This result has similar results with previous research (e.g., Mahpour et al., 2018; Tan, 2017; Whang et al., 2016; Saeedi and Hanzaee, 2018; Zarrad and Debabi, 2015; Abubakar and Ilkan, 2017; Abubakar and Ilkan, 2016).

\section{CONCLUSION}

This research aims to test travel intention model by applying Borobudur temple as a research object. All research hypotheses were supported by data. However, this research also has several limitations such as the application of non-probability sampling design that limits the generalization of the results. Also, this research is a cross-sectional research which only describes one point of situation.

\section{REFERENCES}

Abubakar, A. M., and Ilkan, M. (2016). Impact of Online WOM on Destination Trust and Intention to Travel: A Medical Tourism Perspective. Journal of Destination Marketing and Management. https://doi.org/10.1016/j.jdmm.2015.12.005.

Abubakar, A. M., Ilkan, M., Meshall Al-Tal, R., and Eluwole, K. K. (2017). eWOM, Revisit Intention, Destination Trust and Gender. Journal of Hospitality and Tourism Management. https://doi.org/10.1016/j.jhtm.2016.12.005.

Ahn, T., Ekinci, Y., and Li, G. (2013). Self-Congruence, Functional Congruence, and Destination Choice. Journal of Business Research. https://doi.org/10.1016/j.jbusres.2011.09.009.

Andeas, D. (2010). Why Did The chicken browse the social media. Jakarta: PT Elex Media Komputindo.

Assaker, G., Vinzi, V. E., and O'Connor, P. (2011). Examining the Effect of Novelty Seeking, Satisfaction, and Destination Image on Tourists' Return Pattern: A two factor, non-linear Latent Growth Model. Tourism Management. https://doi.org/10.1016/j.tourman.2010.08.004. 
Chen, Y. C., Shang, R. A., and Li, M. J. (2014). The Effects of Perceived Relevance of Travel Blogs' Content On The Behavioral Intention To Visit A Tourist Destination. Computers in Human Behavior. https://doi.org/10.1016/j.chb.2013.05.019.

Croy, G. (2014). Teaching Tourism, Image and Media Relationships. International Tourism and Media Conference. Retrieved from http://www.buseco.monash.edu.au/units/tru/staff/croy.

Di Pietro, L.; Di Virgilio, F.; Pantano, E. (2012). Social network for the choice of tourist destination: Attitude and behavioural intention. J. Hosp. Tour. Technol. 3, 60-76.

Hawkins, D. I., and Mothersbaugh, D. L. (2010). Consumer Behavior: Building Marketing Strategy. Publish. Retrieved from http://www.amazon.com/dp/0072416882. In Publish.

Hidayat, T. T. N., Chalil, dan Sutomo, M. (2017). Pengaruh Aksesibilitas dan Citra Destinasi Terhadap Niat Berkunjung Kembali ke Telaga Tambing. Jurnal Ilmu Manajemen Universitas Tadulako, 3(2), 201-212.

Isa, S. M., and Ramli, L. (2014). Factors Influencing Tourist Visitation in Marine Tourism: Lessons learned from FRI Aquarium Penang, Malaysia. International Journal of Culture, Tourism, and Hospitality Research. https://doi.org/10.1108/IJCTHR-042013-0016.

Ishida, K., Slevitch, L., and Siamionava, K. (2016). The Effects of Traditional and Electronic Word-of-Mouth on Destination Image: A Case of Vacation Tourists Visiting Branson, Missouri. Administrative Sciences. https://doi.org/10.3390/admsci6040012.

Jalilvand, M. R., and Samiei, N. (2012). The Impact of Electronic Word of Mouth on A Tourism Destination Choice: Testing The Theory of Planned Behavior (TPB). Internet Research. https://doi.org/10.1108/10662241211271563.

Jalilvand, M. R., Ebrahimi, A., and Samiei, N. (2013). Electronic Word of Mouth Effects on Tourists' Attitudes Toward Islamic Destinations and Travel Intention: An Empirical Study in Iran. Procedia - Social and Behavioral Sciences. https://doi.org/10.1016/j.sbspro.2013.06.465.

Jalilvand, M. R., Esfahani, S. S., and Samiei, N. (2011). Electronic Word-Of-Mouth: Challenges and Opportunities. Procedia Computer Science. https://doi.org/10.1016/j.procs.2010.12.008.

Kock, N., and Hadaya, P. (2018). Minimum sample size estimation in PLS- SEM: The inverse square root and gamma- exponential methods. Information Systems Journal, 28(1), 227-261.

Ladhari, R., and Michaud, M. (2015). EWOM Effects on Hotel Booking Intentions, Attitudes, Trust, and Website Perceptions. International Journal of Hospitality Management. https://doi.org/10.1016/j.ijhm.2015.01.010.

Lamba, B., and Agarwal, M. (2014).A study on influence of eWOM: Consumer buying behaviour. The International Journal of Business \& Management, 2(4):237-241.

Mahpour, A., Mamdoohi, A., HosseinRashidi, T., Schmid, B., and Axhausen, K. W. (2018). Shopping Destination Choice in Tehran: An Integrated Choice and Latent Variable Approach. Transportation Research Part F: Traffic Psychology and Behaviour. https://doi.org/10.1016/j.trf.2018.06.045.

Mehmood, S., Liang, C., and Gu, D. (2018). Heritage Image And Attitudes Toward A Heritage Site: Do They Really Mediate The Relationship Between User-Generated 
Content And Travel Intentions Toward A Heritage Site? Sustainability (Switzerland). https://doi.org/10.3390/su10124403.

Nassar, M. A., Mostafa, M. M., and Reisinger, Y. (2015). Factors Influencing Travel to Islamic Destinations: An Empirical Analysis of Kuwaiti Nationals. International Journal of Culture, Tourism, and Hospitality Research. https://doi.org/10.1108/IJCTHR-10-2014-0088.

O'Connor, P. (2010). Managing a hotel's image on Tripadvisor. Journal of Hospitality Marketing and Management. https://doi.org/10.1080/19368623.2010.508007.

Phau, I., Shanka, T., and Dhayan, N. (2010). Destination Image and Choice Intention of University Student Travellers to Mauritius. International Journal of Contemporary Hospitality Management. https://doi.org/10.1108/09596111011053846.

Pratiwi, Y. R. (2017). Pengaruh Word of Mouth Communication terhadap Keputusan Pembelian Konsumen Pada Boardgame Lounge Smart Cafe Pekanbaru. Jom Fisip, $4(1), 1-15$.

Pratminingsih, S. (2014). Roles of Motivation and Destination Image in Predicting Tourist Revisit Intention: A Case of Bandung - Indonesia. International Journal of Innovation, Management and Technology, 5(1). https://doi.org/10.7763/ijimt.2014.v5.479

Radzi, C. W. J. B. W. M., Hui, H., Mohamed, N. A. B., and Jenatabadi, H. S. (2017). Family Food Security and Children's Environment: A Comprehensive Analysis With Structural Equation Modeling. Sustainability (Switzerland). https://doi.org/10.3390/su9071220.

Reza Jalilvand, M., Samiei, N., Dini, B., and Yaghoubi Manzari, P. (2012). Examining The Structural Relationships Of Electronic Word Of Mouth, Destination Image, Tourist Attitude Toward Destination And Travel Intention: An Integrated Approach. Journal of Destination Marketing and Management. https://doi.org/10.1016/j.jdmm.2012.10.001.

Ruslan, R. (2014). Manajemen Public Relations dan Komunikasi. In Manajemen Public Relations \& Media Komunikasi.

Saeedi, H., and Heidarzadeh Hanzaee, K. (2018). The Effects Of Heritage Image On Destination Branding: An Iranian Perspective. Journal of Heritage Tourism. https://doi.org/10.1080/1743873X.2016.1264958.

Setiawan, P. Y., Troena, E. A., Armanu, and Noermijati. (2014). The Effect of e-WOM on Destination Image, Satisfaction and Loyalty. International Journal of Business and Management Invention.

Tan, W. K. (2017). Repeat visitation: A Study from the Perspective of Leisure Constraint, Tourist Experience, Destination Images, and Experiential Familiarity. Journal of Destination Marketing and Management. https://doi.org/10.1016/j.jdmm.2016.04.003.

Tussyadiah, I. P., Wang, D., Jung, T. H., and tom Dieck, M. C. (2018). Virtual Reality, Presence, and Attitude Change: Empirical Evidence from Tourism. Tourism Management. https://doi.org/10.1016/j.tourman.2017.12.003.

Vermeulen, I. E., and Seegers, D. (2009). Tried and tested: The Impact of Online Hotel Reviews on Consumer Consideration. Tourism Management. https://doi.org/10.1016/j.tourman.2008.04.008. 
Whang, H., Yong, S., and Ko, E. (2016). Pop Culture, Destination Images, and Visit Intentions: Theory and Research on Travel Motivations of Chinese and Russian Tourists. Journal of Business Research. https://doi.org/10.1016/j.jbusres.2015.06.020.

Wolf, E. J., Harrington, K. M., Clark, S. L., and Miller, M. W. (2013). Sample Size Requirements for Structural Equation Models: An Evaluation of Power, Bias, and Solution Propriety. Educational and Psychological Measurement. https://doi.org/10.1177/0013164413495237.

$\mathrm{Wu}, \mathrm{C}$. W. (2015). Foreign Tourists' Intentions in Visiting Leisure Farms. Journal of Business Research. https://doi.org/10.1016/j.jbusres.2014.11.024.

Zarrad H, and Debabi M. (2015). Analyzing the Effect of Electronic Word of Mouth on Tourists' attitude toward Destination and Travel Intention. International Research Journal of Social Sciences. 